\title{
Dissolved and particulate nutrient transport dynamics of a small Irish catchment: the River Owenabue
}

\author{
S. T. Harrington ${ }^{1}$ and J. R. Harrington ${ }^{2}$ \\ ${ }^{1}$ Department of Civil, Structural \& Environmental Engineering, Cork Institute of Technology, Cork, Ireland \\ ${ }^{2}$ School of Building \& Civil Engineering, Cork Institute of Technology, Cork, Ireland \\ Correspondence to: S. T. Harrington (sean.harrington@cit.ie)
}

Received: 21 November 2013 - Published in Hydrol. Earth Syst. Sci. Discuss.: 6 January 2014

Revised: - - Accepted: 14 April 2014 - Published: 17 June 2014

\begin{abstract}
The objective of this research was to investigate the relationship between water and sediment discharge on the transport of nutrients: nitrogen and phosphorus. Water discharge, suspended sediment concentration and dissolved and particulate forms of nitrogen and phosphorus were monitored on the $105 \mathrm{~km}^{2}$ River Owenabue catchment in Ireland.

Water discharge was found to have an influence on both particulate and dissolved nutrient transport, but more so for particulate nutrients. The particulate portion of $\mathrm{N}$ and $\mathrm{P}$ in collected samples was found to be 24 and $39 \%$, respectively. Increased particulate nitrogen concentrations were found at the onset of high discharge events, but did not correlate well to discharge. High concentrations of phosphorus were associated with increased discharge rates and the coefficient of determination $\left(r^{2}\right)$ between most forms of phosphorus and both discharge and suspended sediment concentrations were observed to be greater than 0.5 .

The mean TN yield is $4004 \mathrm{~kg} \mathrm{~km}^{-2} \mathrm{yr}^{-1}$ for the full 29-month monitoring period with a mean PN yield of $982 \mathrm{~kg} \mathrm{~km}^{-2} \mathrm{yr}^{-1}, 25 \%$ of the TN yield with the contribution to the yield of PN and PP estimated to be 25 and $53 \%$ respectively. These yields represent a PN and PP contribution to the suspended sediment load of 5.6 and $0.28 \%$ respectively for the monitoring period.

While total nitrogen and total phosphorus levels were similar to other European catchments, levels of bio-available phosphorus were elevated indicating a potential risk of eutrophication within the river.
\end{abstract}

\section{Introduction}

Excess sediment concentrations may have detrimental effects on rivers by reducing temperature, productivity, density, the mass of benthic communities and increasing turbidity (McDowell et al., 2004) with nitrogen (N) and phosphorus (P) being the most commonly measured nutrient parameters when monitoring water quality (Schindler, 2006). Agricultural nutrient loss has been estimated to account for almost $50 \%$ of river pollution in Ireland (McGarrigle and Clenaghan, 2004) and is of significant concern.

The South Western River Basin District (SWRBD) is classified as being the most pristine river basin district in Ireland, with $92 \%$ of surveyed rivers classed as unpolluted (McGarrigle et al., 2010). Geographically, fertiliser application is higher in southern parts of Ireland than in the rest of the country where the national average usage of fertiliser applied to grazed grassland has been estimated at 65,3 and $9 \mathrm{~kg} \mathrm{ha}^{-1}$ for N, $\mathrm{P}$ and potassium respectively. The higher use of fertilisers in the south reflects the more intensive farming and stocking rates (Lalor et al., 2010). High application rates of fertilisers in southern parts of Ireland gives rise to greater risk of non-point pollution to surface waters and one of the main pressures to water quality in the River Owenabue, for example, has been identified as being from diffuse agricultural sources, forestry and from domestic wastewater treatment plants leaching to groundwater (Anon., 2010).

Scanlon et al. (2004) showed that P loading in the agricultural Dripsey catchment in County Cork were entirely due to increases in particulate $\mathrm{P}(\mathrm{PP})$, which were associated with the sediment. Withers et al. (2001) showed that high P levels found in sediment in run-off from agricultural land in the UK 
was caused by large quantities of artificial fertilisers being applied to land over recent decades.

Neill (1989) showed that nitrogen and in particular nitrate in the River Burren in County Carlow, Ireland, follows a sine-like curve whereby concentrations peak in the winter months of January and February and are lowest in the summer months of July and August. This pattern is consistent with the results of a study in the UK on an agricultural catchment in Devon (Webb and Walling, 1985) and can be explained by water moving through the soil and less nutrient take-up during the winter by plant life in addition to plant die-back adding nitrogen to the watercourse, which all contribute to higher $\mathrm{N}$ levels during the winter.

The focus today in many nutrient load studies has been to study the filtered (dissolved) part of the water sample. Usually, samples are passed through $0.45 \mu \mathrm{m}$ filter papers (Drewry et al., 2008; Scanlon et al., 2004) as particles below this size are assumed to be dissolved although larger filter sizes such as $1.2 \mu \mathrm{m}$ are also used (Quilbé et al., 2006; Salvia-Castellví et al., 2005). Filter papers with a $1.2 \mu \mathrm{m}$ retention size are practical for use where a relationship or comparison with suspended sediment concentration is investigated because a $1.2 \mu \mathrm{m}$ pore size is used in most suspended sediment filtration methods. Method 2540 D of the APHA, a commonly used suspended sediment concentration (SSC) testing procedure, defines material passing $2 \mu \mathrm{m}$ as dissolved. There appears to have been little work presented on maintaining analytical consistency by using the same sized filters or by ensuring that only soluble forms are included in the analysis. The use of $1.2 \mu \mathrm{m}$ filters has the effect of increasing the percentage of $\mathrm{N}$ or $\mathrm{P}$ included in the dissolved fraction of the water sample, and correspondingly lowers the particulate fractions compared to studies where finer $0.45 \mu \mathrm{m}$ filter papers are used.

Traditionally, the method of difference has been used to determine the sediment-associated chemical levels of water samples. Firstly, the chemical parameter of the unfiltered whole raw water sample is tested and this is subsequently compared to the filtered sample, with the difference attributed to sediment association. This approach often produces an incorrect result where the filtered sample contains higher levels of the measured chemical than the original unfiltered sample. Apart from sample contamination, analytical error is the only other source of error. The errors are introduced when reporting levels that are on or near the report limit of the equipment or using techniques involving digestion that do not completely release all the available chemicals for analysis (Horowitz, 2008). In fact, the digestion procedures of most chemical and trace element analysis methods are not intended nor designed to completely solubilise sediment associated constituents (Fishman and Friedman, 1989; Eaton et al., 2005). Furthermore, the extent to which the sediment in a sample can be dissolved depends on the matrix of the sample. For example, carbon based sediments may be completely dissolved while igneous or metamorphic based sediments do not readily dissolve (Horowitz, 2008).

In this paper, we investigate the relationships between flow rate, turbidity and nutrient delivery in the Owenabue catchment. Additionally, we analyse the contribution of particulate nutrient concentrations during high flow or high turbidity events and show that particulate transport of nutrient forms a significant portion of overall nutrient transport.

\section{Study area}

This study focuses on the River Owenabue and its catchment (Fig. 1) which is located in the SWRBD which was established under the EU Water Framework Directive (WFD). The SWRBD covers an area of $11180 \mathrm{~km}^{2}$. Mean annual rainfall at the nearby Cork Airport weather gauging station for the period April 1962 to May 2012 is approximately $1208 \mathrm{~mm}$.

The $22.7 \mathrm{~km}$ long River Owenabue emerges at an elevation of $110 \mathrm{~m}$ above Malin Head datum, has an average gradient of $6.3 \mathrm{~m} \mathrm{~km}^{-1}$ and drains an area of $105 \mathrm{~km}^{2}$. It discharges to the Cork Harbour which is a nutrient sensitive area subject to various regulations arising from the EU Urban Waste Water Treatment directive (91/271/EEC) and the Nitrates Directive (91/676/EEC). Soil cover consists mainly of acid brown earths and brown podzolics located in the northern part of the catchment. Surface/groundwater gleys are present in the southern section of the catchment together with small amounts of lithosols, regosols and peaty podzols. The catchment is $97 \%$ agricultural land, primarily under pasture and tillage. The remainder consists of small pockets of forestry and urban settlements. The catchment hill slopes are quite steep and response to rainfall is quick with a noticeable increase in river stage within an hour of a significant rainfall event. There is an associated suspended sediment response in the river.

The River Owenabue has been classified as being of moderate to poor status under the WFD and also of being at risk of not meeting good status by 2015 . The objective for the 2015 to 2021 reporting period is to improve river water quality. The poor status of the river can be attributed to the results of the macroinvertebrate tests rather than the physiochemical testing, and in fact, the river has been classed as high status in terms of physio-chemical status (Anon., 2010),

Water level has been recorded at the gauging station at Ballea Bridge Lower (Fig. 1) on the River Owenabue since 1956. Water level is converted to discharge using a stage discharge curve. Data are available in digital format at $15 \mathrm{~min}$ intervals. The mean discharge for the $103 \mathrm{~km}^{2}$ catchment contributing to the gauging station is $2.4 \mathrm{~m}^{3} \mathrm{~s}^{-1}$ with mean annual maximum discharge over 10 times the mean discharge. 


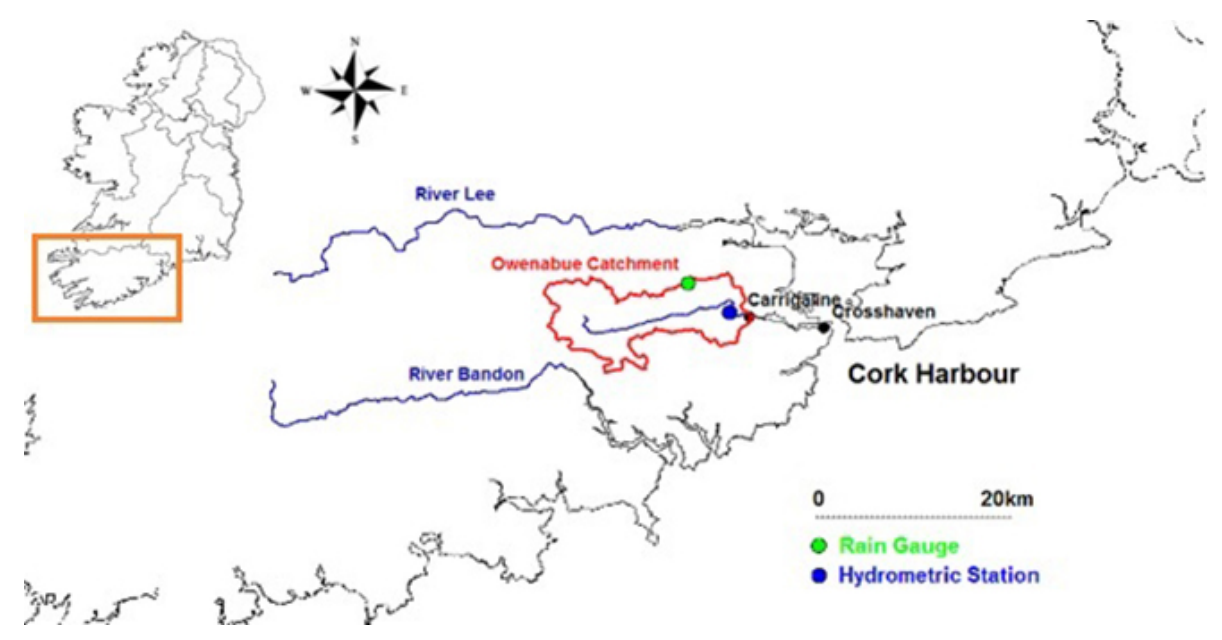

Figure 1. Location of the River Owenabue catchment and gauging station.

\section{Methodology}

\subsection{Analysis}

Nutrient and SSC concentrations were measured generally weekly between 8 January 2010 and 29 January 2012. Additional samples were collected during November 2009 and January 2010 when large storm events occurred. The data base of nutrient concentrations totals 103 samples.

One litre samples were collected in plastic bottles and tested within $24 \mathrm{~h}$ of collection or immediately frozen and tested within 6 weeks. Whatman ${ }^{\circledR} \mathrm{GF} / \mathrm{C}$ filters, $1.2 \mu \mathrm{m}$ pore size, were used to filter the water samples to determine dissolved nutrient parameters. This provided analytical consistency between the suspended sediment analysis and the chemical analysis.

The nutrient parameters monitored were: total phosphorus (TP), particulate phosphorus (PP), total reactive phosphorus (TRP), soluble reactive phosphorus (SRP), total dissolved phosphorus (TDP), total nitrogen (TN), particulate nitrogen (PN), total inorganic nitrogen (TIN), dissolved inorganic nitrogen (DIN) and total dissolved nitrogen (TDN).

Testing methodologies were as detailed by the American Public Health Association (Eaton et al., 2005), namely persulfate digestion (TP, TDP, TN, TDN), ascorbic acid (TRP, SRP) and cadmium reduction (DIN, TIN). PN was calculated as the difference between TN and TDN and PP is the difference between TP and TDP. As an accuracy check, standard samples were included in the analysis of all chemical constituents.

Where the reported concentration of a dissolved species of a sample was larger than the corresponding total concentration, the total concentration was corrected to ensure that the concentration was equal to that of the filtered sample. This procedure was necessary for $23 \mathrm{TN}$ results and $6 \mathrm{TP}$ results with the average adjustment being 1.09 and $0.02 \mathrm{mg} \mathrm{L}^{-1}$, re- spectively. The testing method for both dissolved and total concentration determination is the same, and both were carried out using a subsamples from a single sample bottle and using the same blank. Consequently, we believe that the errors are related to the filtration process as discussed by Jarvie et al. (2002).

\subsection{Load calculation}

The nutrient load from a catchment over a period of time can be estimated by integrating, over time, the product of river discharge and nutrient concentration:

$L_{\mathrm{c}}=\int_{t_{1}}^{t_{2}} Q_{t} C_{t} \mathrm{~d} t$,

where $L_{\mathrm{c}}$ is the load over a time period $\left(t_{2}-t_{1}\right), Q_{t}$ is the discharge at time $t, C_{t}$ is the nutrient concentration at time $t$, and $\mathrm{d} t$ is a time interval of infinitesimal length. $C$ is measured in $\mathrm{mg} \mathrm{L}^{-1}$ and $Q$ is measured in $\mathrm{m}^{3} \mathrm{~s}^{-1}$ yielding $L_{\mathrm{c}}$ in $\mathrm{g}$ for the selected time period.

Where there are omissions or gaps in the record of nutrient concentrations, a means of estimating the unknown concentration is required. Where such situations arise in suspended sediment load analysis, the SSC is often estimated from the discharge using a suspended sediment rating curve between discharge and suspended sediment.

A similar approach can often be adopted for some $\mathrm{P}$ parameters, but $\mathrm{N}$ is not always well explained by either discharge or suspended sediment concentration (Jarvie et al., 1998) so alternative methodologies must be adopted. Linear interpolation for nitrate load calculation has been found to be the best performing method by Kronvang and Bruhn (1996), Moatar and Maybeck (2005) and Zamyadi et al. (2007). Beale's ratio estimator has been shown to perform well for medium to large sized watersheds (Cohn, 1995); however, 


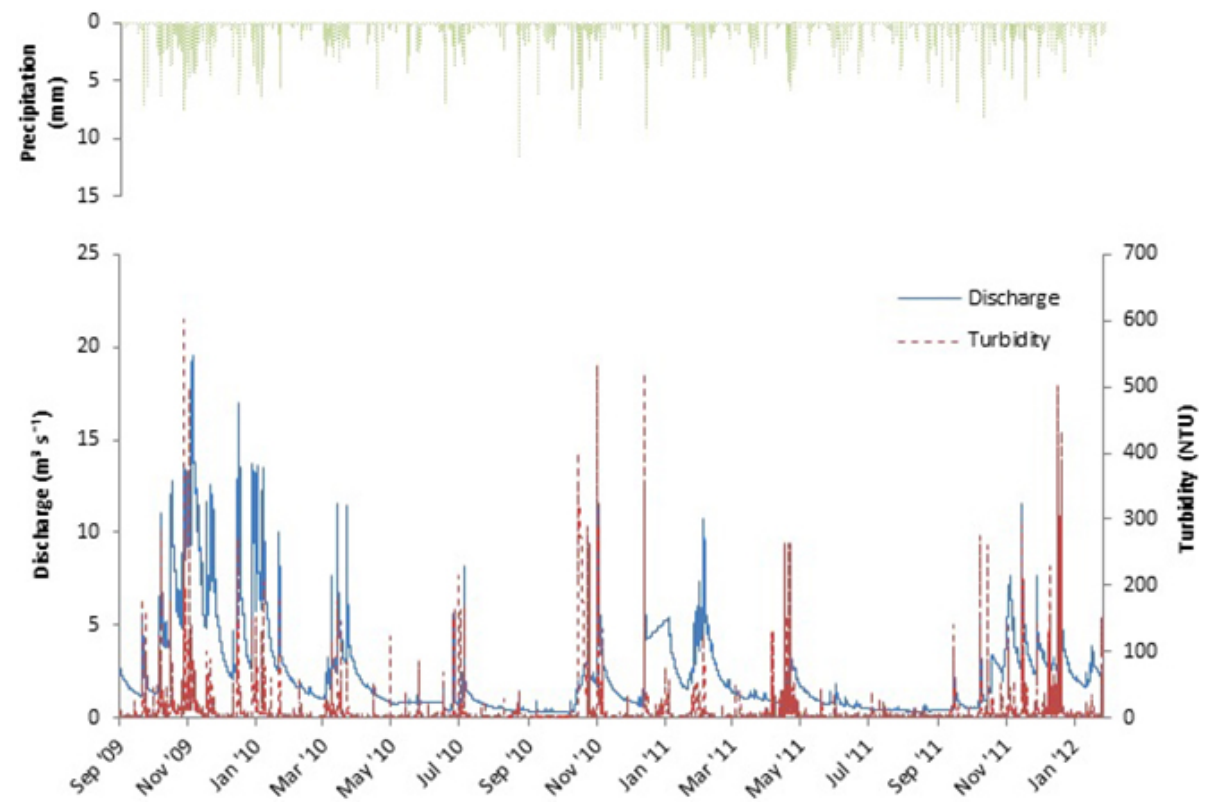

Figure 2. Precipitation, discharge and turbidity values during the monitoring period.

it appears to be unverified at smaller scales (Zamyadi et al., 2007). Smart et al. (1999) found that a model which estimates nitrate concentrations from a sine curve gave the best results for the River Don in Aberdeen, Scotland, where concentrations of nitrate ranged between 1 to $6 \mathrm{mg} \mathrm{L}^{-1}$ over $11 \mathrm{yr}$ of data and displayed a strong seasonal pattern.

To estimate loads in this paper, extrapolation from the regression curve was used to calculate concentration values when $50 \%$ or more of the dependant variable was explained by the $Q$ or in situ turbidity (Turbi) and was statistically significant $\left(r^{2} \geq 0.5\right.$ and a $p$ value $\left.\leq 0.001\right)$. A similar approach has been undertaken by Quilbé et al. (2006) and Lu et al. (2011). Where this was not the case, concentration values were interpolated to fill the gaps in the daily record assuming that concentration changed at a constant rate per day. Loads for a given time period were then calculated as

$L_{\mathrm{e}}=\sum_{i=1}^{n} C_{i} Q_{i}$

where $L_{\mathrm{e}}$ is the average estimated yield in $\mathrm{g} \mathrm{s}^{-1}, C_{i}$ is the concentration in $\mathrm{mg} \mathrm{L}^{-1}$ for data point $i, Q_{i}$ is the measured discharge in $\mathrm{m}^{3} \mathrm{~s}^{-1}$ for data point $i$ and $n$ is the total number of records.

\section{Results}

\subsection{Hydrology}

Figure 2 shows the precipitation, flow hydrograph and turbidity signal for the monitoring period. Rainfall and river discharge are typically larger in the metrological Irish winter months of November to January and lower values are found for the July to September time period. Rainfall in $2011(1014 \mathrm{~mm})$ was greater than the annual rainfall in 2010 $(859 \mathrm{~mm})$ and both years were "drier" than the long-term annual average $(1208 \mathrm{~mm})$ following a very "wet" year in 2009 $(1574 \mathrm{~mm})$.

Maximum total monthly rainfall over the monitoring period was $246.7 \mathrm{~mm}$ in November 2009 while the lowest monthly total was $17.1 \mathrm{~mm}$ in August 2010. Serious flooding was reported throughout the SWRBD during November 2009 period.

The River Owenabue exhibits a flashy hydrograph as seen in Fig. 2 with suspended sediment concentrations and sediment-associated nutrient concentrations responding quickly to high flow events. Typical events involve a rapid increase in flow rate early in the event, driven by the small catchment and steep catchment hill slopes. The time to peak of a typical event is of the order of hours. At the monthly scale, monthly discharge was observed to be greater than monthly rainfall for 8 months over the monitoring period, indicating that the catchment was regularly saturated. Detailed analysis of the catchment hydrology in relation to sediment transport is presented in Harrington and Harrington (2012).

The sampling programme resulted in a representative range of the flow regime being sampled. The minimum, average and maximum flow rates over which samples were collected were $0.27,3.22$ and $16.66 \mathrm{~m}^{3} \mathrm{~s}^{-1}$, respectively compared with the equivalent values of the continuous record during the monitoring period of $0.27,2.31$ and $19.59 \mathrm{~m}^{3} \mathrm{~s}^{-1}$. 

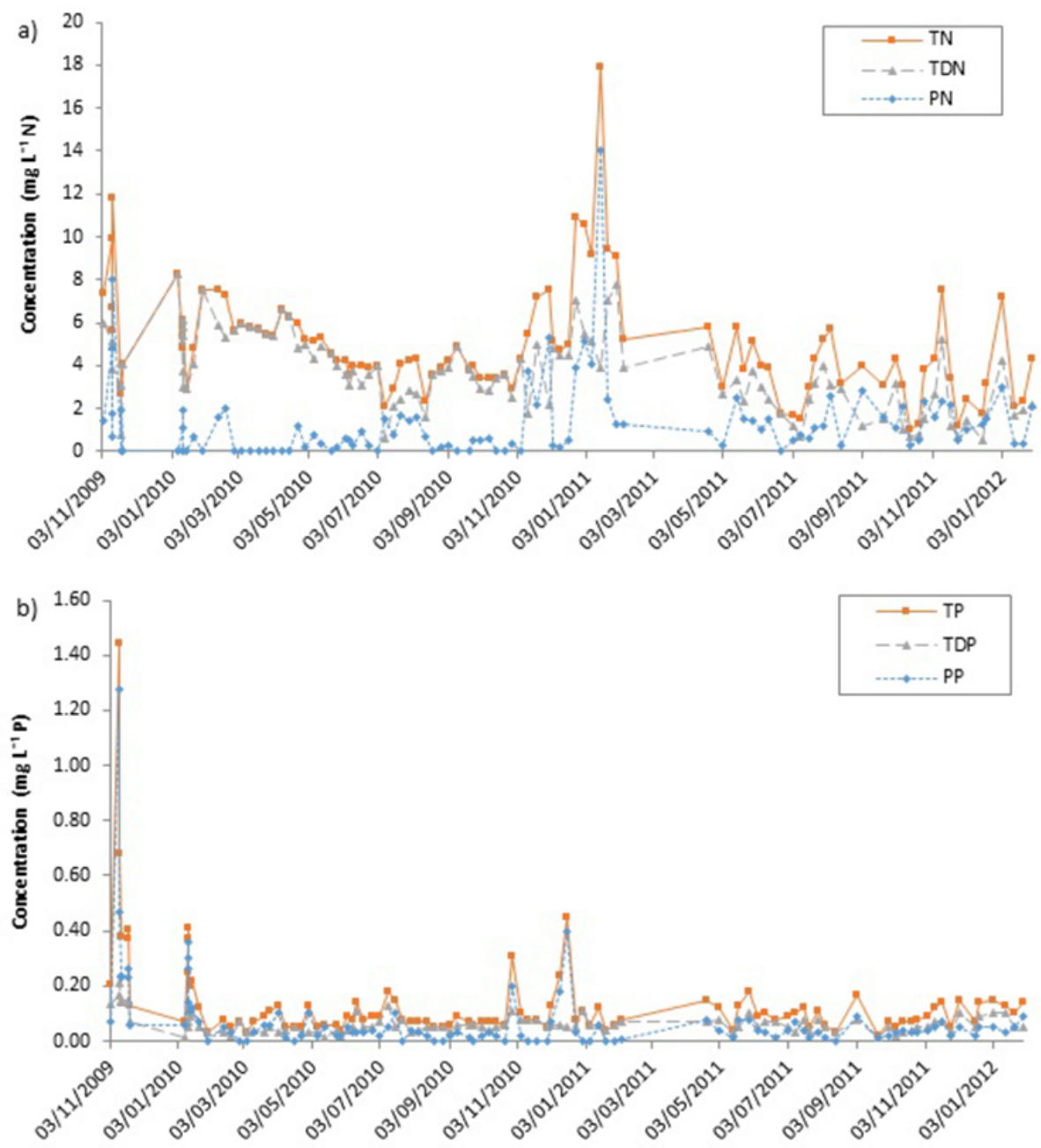

Figure 3. Concentrations of (a) nitrogen and (b) phosphorus during the sampling period.

\subsection{Concentrations}

The largest TN concentrations occur during the winter months of November, December and January (Fig. 3a). Concentrations were lowest during the July to September period. The annual mean TN concentrations for 2010 and 2011 are 4.7 and $4.6 \mathrm{mg} \mathrm{L}^{-1}$, respectively.

The range in TDN was large with concentrations varying between 0.5 and $8.3 \mathrm{mg} \mathrm{L}^{-1}$. The variation in $\mathrm{PN}$ was larger with concentrations ranging from 0 to $14 \mathrm{mg} \mathrm{L}^{-1}$. TDN dominates the TN measurement, with the mean TDN content of the samples being $76 \%$. The variation of TDN content was high with a range between 22 and $100 \%$ of the TN measurement. Correspondingly, PN constituted $24 \%$ of the TN concentrations of the samples, with a range from 0 to $78 \%$.

TP concentrations are generally higher in winter although the winter of 2011 had notably lower concentrations (Fig. 3b). Annual mean TP concentrations were $0.1 \mathrm{mg} \mathrm{L}^{-1}$ in both 2010 and 2011. TP is dominated by TDP, with TDP concentrations ranging from 0.01 to $0.19 \mathrm{mg} \mathrm{L}^{-1}$ and having an average concentration of $0.06 \mathrm{mg} \mathrm{L}^{-1}$. PP was found to vary from 0.0 to $1.28 \mathrm{mg} \mathrm{L}^{-1}$ indicating PP to be much more variable than dissolved phosphorus. TDP dominates the TP measurement, with the mean TDP content of the samples being $61 \%$. The variation of TDP content was high with a range between 11 and $100 \%$ of the TN measurement. Correspondingly, PN constituted $39 \%$ of the TP concentrations of the samples, with a range from 0 to $89 \%$.

\subsection{Nutrient relationships and yields}

Table 1 shows the result of a correlation analysis between the concentrations of the measured nutrient species. Both linear and power-based regressions were investigated with the largest $r^{2}$ values reported. All five regressions were found to be statistically significant ( $p$ values $<0.001$ ). SSC, TP, TRP, and PP were all found to have $r^{2}$ values (coefficient of determination) greater than 0.5 when regressed linearly against in situ turbidity (Turbi). In particular, TP and PP were very well correlated with turbidity. Based on the correlation between 
Table 1. Correlation matrix of $r^{2}$ values from regression for the measured variables on the River Owenabue.

\begin{tabular}{|c|c|c|c|c|c|c|c|c|c|c|c|c|c|}
\hline & $Q$ & $\operatorname{Turb}_{i}$ & SSC & $\mathrm{TN}$ & TDN & TIN & DIN & $\mathrm{TP}$ & TDP & TRP & SRP & PP & PN \\
\hline \multicolumn{14}{|l|}{$Q$} \\
\hline $\operatorname{Turb}_{i}$ & $\underline{0.568}$ & & & & & & & & & & & & \\
\hline SSC & 0.355 & $\underline{0.860}$ & & & & & & & & & & & \\
\hline $\mathrm{TN}$ & 0.089 & $\overline{0.021}$ & 0.038 & & & & & & & & & & \\
\hline TDN & 0.057 & 0.008 & 0.009 & $\underline{0.529}$ & & & & & & & & & \\
\hline TIN & 0.044 & 0.087 & 0.080 & 0.461 & 0.325 & & & & & & & & \\
\hline DIN & 0.056 & 0.058 & 0.057 & $\underline{0.748}$ & 0.441 & $\underline{0.748}$ & & & & & & & \\
\hline $\mathrm{TP}$ & 0.379 & $\underline{0.804}$ & $\underline{0.878}$ & $\overline{0.036}$ & 0.003 & $\overline{0.071}$ & 0.057 & & & & & & \\
\hline TDP & 0.368 & $\overline{0.363}$ & $\overline{0.306}$ & 0.020 & 0.001 & 0.042 & 0.190 & 0.464 & & & & & \\
\hline TRP & 0.487 & $\underline{0.557}$ & $\underline{0.520}$ & 0.011 & 0.017 & 0.159 & 0.124 & $\underline{0.593}$ & $\underline{0.541}$ & & & & \\
\hline SRP & $\underline{0.603}$ & $\overline{0.527}$ & $\overline{0.414}$ & 0.006 & 0.001 & 0.108 & 0.090 & $\overline{0.502}$ & $\overline{0.637}$ & $\underline{0.749}$ & & & \\
\hline PP & $\overline{0.389}$ & $\underline{0.778}$ & 0.886 & 0.037 & 0.007 & 0.043 & 0.041 & $\overline{0.967}$ & $\overline{0.277}$ & $\overline{0.495}$ & 0.381 & & \\
\hline PN & 0.160 & 0.018 & 0.028 & $\underline{0.607}$ & 0.003 & 0.210 & 0.008 & 0.032 & 0.037 & 0.022 & 0.011 & 0.026 & \\
\hline
\end{tabular}

Note: italic font indicates linear regressions, bold font indicates power-based regression and underlined values are those where the regression equation explains greater than $50 \%$ of the variation.

Table 2. Annual nutrient yields $\left(\mathrm{kg} \mathrm{km}^{-2} \mathrm{yr}^{-1}\right)$ for the River Owenabue for the full years of 2010 and 2011 and for the entire monitoring period (16 September 2009 to 9 February 2012).

\begin{tabular}{lcccccccccc}
\hline & TN & TDN & TIN & DIN & PN & TP & TDP & TRP & SRP & PP \\
\hline 2010 & 3353 & 2853 & 3330 & 2791 & 500 & 79.0 & 31.2 & 28.1 & 18.4 & 43.0 \\
2011 & 3141 & 1857 & 3123 & 2219 & 1284 & 59.8 & 36.6 & 24.0 & 15.4 & 27.1 \\
Entire monitoring & 4004 & 3022 & 3662 & 2878 & 982 & 92.6 & 51.9 & 33.7 & 22.9 & 48.7 \\
period (annualised) & & & & & & & & & & \\
\hline
\end{tabular}

$\mathrm{P}$ parameters and turbidity, $\mathrm{P}$ parameters were extrapolated from their respective regression curves with turbidity for the purpose of calculating P loads. Nitrogen loads were calculated using the method in Eq. (2).

Yields of nitrogen and phosphorus passing the gauging station are presented in Table 2 for the years 2010, 2011 and also for the entire monitoring period. The mean TN yield is $4004 \mathrm{~kg} \mathrm{~km}^{-2} \mathrm{yr}^{-1}$ for the full monitoring period with a mean PN yield of $982 \mathrm{~kg} \mathrm{~km}^{-2} \mathrm{yr}^{-1}, 25 \%$ of the TN yield. Mean TP yield is $92.6 \mathrm{~kg} \mathrm{~km}^{-2} \mathrm{yr}^{-1}$ with a mean PP yield of $48.7 \mathrm{~kg} \mathrm{~km}^{-2} \mathrm{yr}^{-1}, 53 \%$ of the TP yield. These yield values are highly influenced by the major storm event of 2009 as illustrated in Table 2 where the mean yields for the full years of 2010 and 2011 are much lower. The mean contribution of PN and PP is estimated to be 5.66 and $0.28 \%$, respectively of the annualised suspended sediment load which is $17331 \mathrm{~kg} \mathrm{~km}^{-2} \mathrm{yr}^{-1}$.

\section{Discussion}

\subsection{Nitrogen and phosphorus concentrations}

The pattern of TN concentrations on the River Owenabue are consistent with other studies where concentrations are greater in winter and lower in the summer (Webb and
Walling, 1985; Neill, 1989). Neill (1989) found an average nitrate concentration of $5.1 \mathrm{mg} \mathrm{L}^{-1}$ for the River Burren in Ireland with a range of nitrate levels from 2 to $9 \mathrm{mg} \mathrm{L}^{-1}$, while this paper presents a range of 2 to $7 \mathrm{mgL}^{-1}$ on the River Owenabue. In the River Don in Aberdeen, Scotland, Smart et al. (1999) found that concentrations of nitrate ranged between 1 and $6 \mathrm{mg} \mathrm{L}^{-1}$ over $11 \mathrm{yr}$ of data and displayed a strong seasonal pattern. A similar range ( 0.1 to $7 \mathrm{mg} \mathrm{L}^{-1}$ ) was found for the River Dee in Scotland by Stutter et al. (2007).

The annual mean concentration of TRP on the River Owenabue over the monitoring period was $0.05 \mathrm{mg} \mathrm{L}^{-1}$ which is in excess of the European Communities Environmental Objectives (Surface Water) Regulations 2009 for achieving good status.

Discharge was found to be an important factor which influences the particulate fractions of nitrogen and phosphorus. For example, $\mathrm{PN}$ was found to be the dominant $\mathrm{N}$ parameter in $11 \%$ of the water samples and these samples have an average discharge of $3.46 \mathrm{~m}^{3} \mathrm{~s}^{-1}$, which is $107 \%$ of the average discharge over which all the samples were collected. This indicates that increased flow increases the PN portion of the TN sample. Results were more pronounced for phosphorus concentrations where the mean discharge when PP 
dominated samples was $180 \%$ of the mean discharge over all the samples.

Mean TP concentrations on the River Owenabue are consistent with a value of $0.15 \mathrm{mg} \mathrm{L}^{-1}$ for the small $14 \mathrm{~km}^{2}$ Dripsey catchment located nearby (Jordan et al., 2005) and also with values reported by Scanlon et al. (2004) in a nearby small sub-catchment of the Dripsey. Mainstone et al. (2008) reference a target value, citing the standards set forth in the 2004 "Common Standards" drawn up by UK nature conservation agencies, of $0.06 \mathrm{mg} \mathrm{L}^{-1}$ for total reactive phosphorus (TRP) for rivers underlain by sandstones and mudstones with background TRP levels of $0.02 \mathrm{mg} \mathrm{L}^{-1}$. The mean TRP value on the River Owenabue for the study period is $0.05 \mathrm{mg} \mathrm{L}^{-1}$ suggesting it to be on the threshold of being polluted. In addition, the mean concentrations of SRP on the River Owenabue $\left(0.03 \mathrm{mg} \mathrm{L}^{-1}\right)$ were much higher than those found in the unpolluted River Dee, Scotland (Stutter et al., 2007), which is of particular concern because SRP is the most immediately bioavailable form of phosphorus to aquatic organisms.

$\mathrm{N}: \mathrm{P}$ stoichiometry is widely used to define $\mathrm{P}$ or $\mathrm{N}$ limitation for plankton growth, which leads to eutrophication. A molecular N:P ratio greater than 16 (Redfield ratio) indicates $\mathrm{P}$ to be the limiting nutrient, while N:P ratios lower than 16 indicate $\mathrm{N}$ to be the limiting nutrient. The mean $\mathrm{N}: \mathrm{P}$ ratio of the River Owenabue for the entire study period was 43, indicating that plankton, biofilm and plant growth and thus eutrophication in the River Owenabue is controlled by $\mathrm{P}$ inputs, rather than $\mathrm{N}$ inputs. This is important in the context of the WFD where rivers must achieve good status by 2015 and the River Owenabue has been identified as being at risk of not meeting this target based on both point source pollution from wastewater treatment plants and diffuse sources such as septic tanks which have a high P content.

\subsection{Storm event nutrient dynamics}

The dynamics between PN and TDN vary considerably at the intra event scale. Increases in TP and TN during a typical storm event of January 2010 were found to be primarily driven by increases in PP and PN. The hydrology of the event is typical of many events observed on the River Owenabue (Harrington and Harrington, 2012). Maximum peak flow recorded during the event was approximately $13.7 \mathrm{~m}^{3} \mathrm{~s}^{-1}$, compared to a discharge of $3.1 \mathrm{~m}^{3} \mathrm{~s}^{-1}$ at the beginning of the event. Initially, there is a sharp rise in flow rate starting after midnight on 12 January. The flow rate peaks at approximately $14 \mathrm{~m}^{3} \mathrm{~s}^{-1}$ after $12 \mathrm{~h}$ and flows remained high into the 13th when they began to decline rapidly. Early on the 15th, flow rate began to rise rapidly again for a secondary peak.

In terms of nutrient delivery, the profile of both $\mathrm{N}$ and $\mathrm{P}$ is shown in Fig. 4 for the event. Initially there is a sharp decrease in TDN (Fig. 4a) which is partially offset by an increase in PN concentrations which are sufficiently large initially to reverse the overall downward trend in $\mathrm{TN}$ concentration. When the initial flush of PN passes, the TN concen- tration continues to decline. The decline in TN indicates that the nitrogen in the river is being diluted by increased flows, which has also been reported by others (Salvia-Castellví et al., 2005). The most likely cause of the dilution is that the primary input to the river is from overland flow rather than through the sub-soil, where nutrient leaching would be higher.

A similar, but stronger trend is found for TP during the same storm event (Fig. 4b). A significant increase in PP results in a significant increase in TP concentrations. The increase in PP is due to the mobilisation of suspended sediment during the initial period of the storm, whereas the sustained slightly elevated TDP concentrations most likely arise from the leaching of $\mathrm{P}$ from soils through sub-surface flow. The TP loads, and in particular the PP load, is therefore mainly determined by infrequent storm-based events, and particularly on the rising limb of the hydrograph of such events. The high correlation of PP with turbidity as presented in Table 1 is further evidence of the important relationship between PP and suspended sediment transport.

\subsection{Nutrient loads and yields}

Seasonal loads are presented Fig. 5. Winter loads of TN vary from 96 to $311 \mathrm{t}$ for the three winters monitored. TP loads vary from 3.2 to to $8.4 \mathrm{t}$. During the winter, PN and PP contribute 27 and $55 \%$, respectively to the total $\mathrm{N}$ and total $\mathrm{P}$ load while during the summer PN and PP contribute 19 and $45 \%$, respectively to the total $\mathrm{N}$ and total $\mathrm{P}$ loads.

Both $\mathrm{P}$ and $\mathrm{N}$ loads are primarily transported in the winter months with loads decreasing through spring, summer and autumn (Fig. 5). In the winter, TN loads increase primarily due to an increase in TDN, while TP increases due to elevated TDP and PP loads. The increase in the particulate fractions can be explained by soil erosion and catchment run-off which enters the river during winter floods. This finding is consistent with other studies (Lu et al., 2011) and is supported by the high proportion of the suspended sediment load delivered during high flow events on the River Owenabue (Harrington and Harrington, 2012).

The mean annual yield of TN $\left(4004 \mathrm{~kg} \mathrm{~km}^{-2} \mathrm{yr}^{-1}\right)$ is larger than a reported value of $2545 \mathrm{~kg} \mathrm{~km}^{-2} \mathrm{yr}^{-1}$ for the $155 \mathrm{~km}^{2}$ Burren catchment in Ireland (Neill, 1989) but the 2010 and $2011 \mathrm{TN}$ yields, which do not include the major storm event of 2009, compare well to the Burren Catchment. The TN yield is approximately double that of the $73 \mathrm{~km}^{2}$ Cadière River in France where $\mathrm{TN}$ yields were $2217 \mathrm{~kg} \mathrm{~km}^{-2} \mathrm{yr}^{-1}$ (Gouze et al., 2008).

The mean annual TP yield $\left(92.6 \mathrm{~kg} \mathrm{~km}^{-2} \mathrm{yr}^{-1}\right)$ is slightly higher than that for the similarly sized River Cherwell catchment in England where the TP yield was $76.4 \mathrm{~kg} \mathrm{~km}^{-2} \mathrm{yr}^{-1}$ (May et al., 2001) and also corresponds with a reported range of $54-82 \mathrm{~kg} \mathrm{~km}^{-2} \mathrm{yr}^{-1}$ found for similar sized catchments in Italy by Marchetti and Verna (1992). A similar range of values was found in Sweden $\left(10-90 \mathrm{~kg} \mathrm{~km}^{-2} \mathrm{yr}^{-1}\right)$ where the 

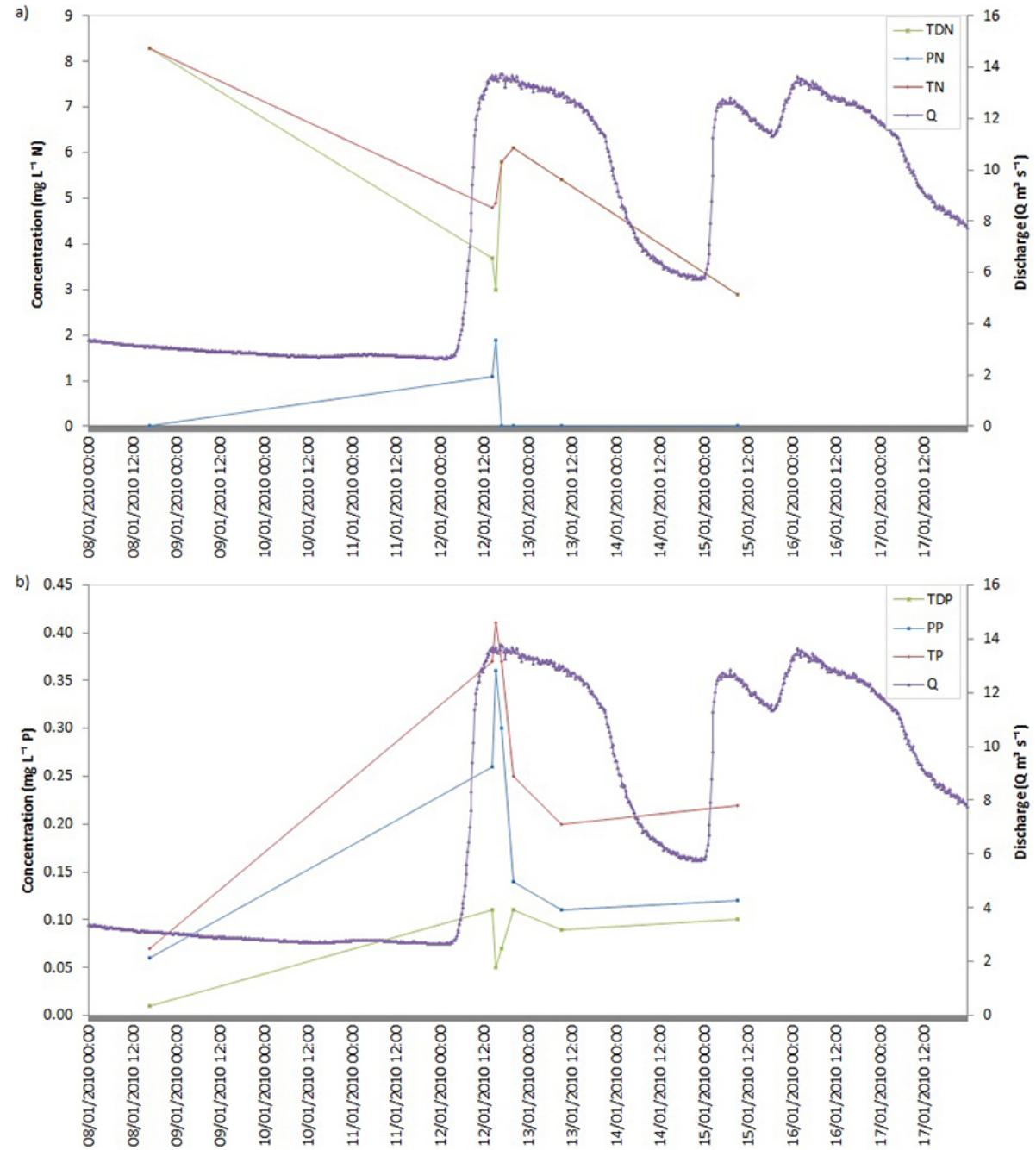

Figure 4. Discharge and (a) nitrogen and (b) phosphorus concentrations during a storm event from January 2010.

higher values were attributed to heavier soils types and a higher proportion of annual crops and associated ploughing (Kyllmar et al., 2006).

\section{Conclusions}

The results show that discharge and SSC influence the concentration of nitrogen and phosphorus. Nutrient concentrations were found to be highly variable. Significant variations were observed at the within-event and seasonal scale. At the seasonal scale most of the SSC, nitrogen and phosphorus are transported in the winter months when run-off rates are generally higher. At the within-event scale, the proportions of particulate and dissolved nutrients vary due to changes in the source of supply. Typically, particulate fractions initially dominate before becoming exhausted, and dissolved forms become more dominant.
Turbidity was found to be a suitable surrogate for phosphorus parameters and in particular TP and PP but nitrogen parameters were not well correlated with either turbidity or discharge, as is generally found in the literature. Estimated $\mathrm{TN}$ and TP yields were found to be at the higher end of scale in terms of UK and European catchments, but this was significantly influenced by the large storm event of 2009.

The particulate portion of $\mathrm{N}$ and $\mathrm{P}$ was found, on average, to contribute 24 and $39 \%$ of TN and TP respectively for the samples collected. Overall, the yield of PN and PP was estimated to be 25 and $53 \%$ respectively of the TN and TP yields. Phosphorus inputs, in particular from diffuse agricultural sources are a significant potential risk given that they are highly dependent on run-off processes, unlike point sources.

TN concentrations were diluted during storm events, despite an initial increase in particulate concentration signifying that its transport mechanism does not respond quickly to river discharge or overland flow. Conversely, TP was found to 

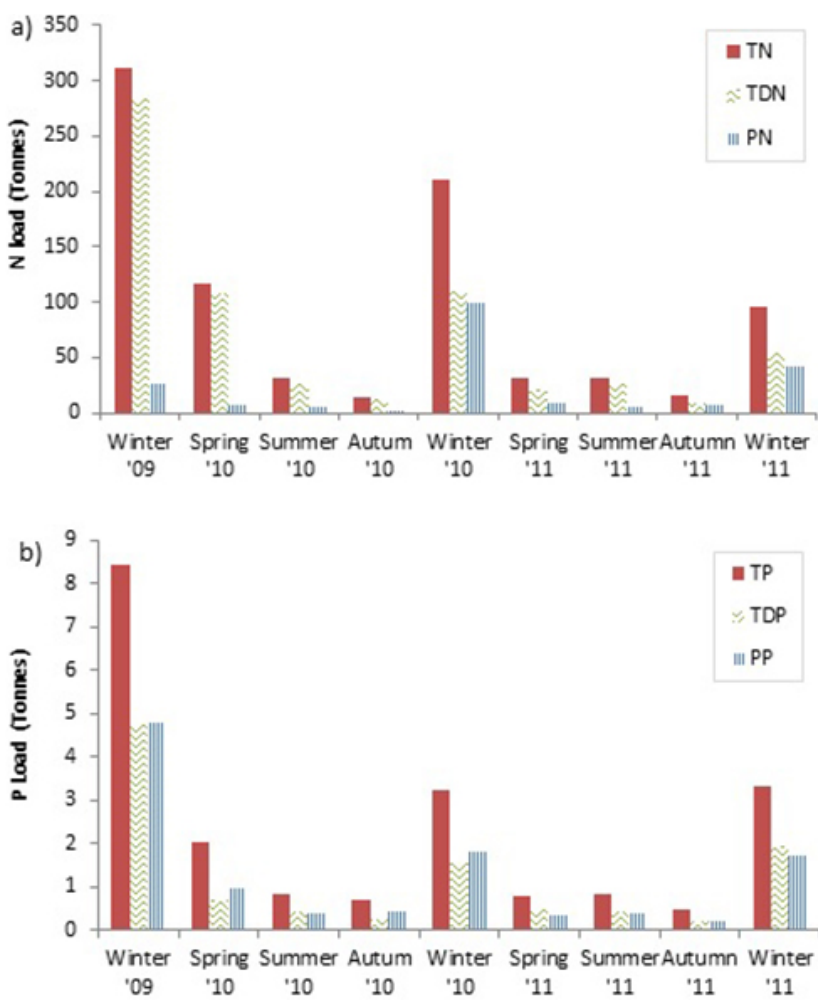

Figure 5. Seasonal loads of (a) nitrogen and (b) phosphorus on the River Owenabue.

respond quickly to river discharge and overland flow where both the dissolved and particulate fractions of phosphorus increase during storm events.

Acknowledgements. The authors wish to acknowledge the research funding received from the Government of Ireland/Institutes of Technology Technological Sector Research Strand I Postgraduate R \& D Skills Programme. The authors also wish to acknowledge the support received from the Office of Public Works for providing discharge data and Met Éireann for providing rainfall data.

Edited by: P. Grathwohl

\section{References}

Anon.: Water Matters: Our Plan! - South Western River Basin District Management Plan (2009-2015), South Western River Basin District Project Office, Environmental Department, Cork County Council, Inniscarra, Co, Cork, 2010.

Cohn, T. A.: Recent advances in statistical methods for the estimation of sediment and nutrient transport in rivers, US National Report to International Union of Geodesy and Geophysics (19911994), Rev. Geophys., 3, 1117-1133, 1995
Drewry, J. J., Newham, L. T. H., and Croke, B. F. W.: Suspended sediment, nitrogen and phosphorus concentrations and exports during storm-events to the Tuross estuary, Australia, Environ. Manage., 90, 879-887, doi:10.1016/j.jenvman.2008.02.004, 2008.

Eaton, A. D., Glesceri, L. S., Rice, E. W., and Greenberg, A. E. (Eds.): Standard methods for the examination of water and wastewater, 21st Edn., American Public Health Association, American Water Works Association, Water Environment Association, APHA, 1015 Fifteenth Street, NW, Washington, DC 20008, 2005.

European Communities Environmental Objectives (Surface Water) Regulations: S.I. No. 272 of 2009, Stationery Office, Dublin, 2009.

Fishman, M. J. and Friedman, L. C. (Eds): Methods for the determination of inorganic substances in water and fluvial sediments, Techniques of water-resources investigations of the USGS, 3rd Edn., Chapter A1, Book 5, USGS, Washington, D.C., 545 pp., 1989.

Gouze, E., Raimbault, P., Garcia, N., Bernard, G., and Picon, P.: Nutrient and suspended matter discharge by tributaries into the Berre Lagoon (France): The contribution of flood events to the matter budget, C. R. Geosci., 340, 233-244, 2008.

Harrington, S. T. and Harrington, J. R.: The influence of storm based events on the suspended sediment flux in a small scale river catchment in Ireland, Monitoring, Simulation, Prevention and Remediation of Dense and Debris Flows IV, WIT Press, Southampton, UK, 2012.

Horowitz, A. J.: Determining annual suspended sediment and sediment-associated trace element and nutrient loads, Sci. Total Environ., 400, 315-343, 2008.

Jarvie, H. P., Whitton, B. A., and Neal, C.: Nitrogen and phosphorus in east coast British rivers: Speciation, sources and biological significance, Sci. Total Environ., 210/211, 79-109, 1998.

Jarvie, H. P., Withers, J. A., and Neal, C.: Review of robust measurement of phosphorus in river water: sampling, storage, fractionation and sensitivity, Hydrol. Earth Syst. Sci., 6, 113-131, doi:10.5194/hess-6-113-2002, 2002.

Jordan, P., Menary, W., Daly, K., Kiely, G., Morgan, G., Byrne, P., and Moles, R.: Patterns and processes of phosphorus transfer from Irish grassland soils to rivers - integration of laboratory and catchment studies, J. Hydrol., 304, 20-34, 2005.

Kronvang, B. and Bruhn, A. J.: Choice of sampling strategy and estimation method for calculating nitrogen and phosphorous transport in small lowland streams, Hydrol. Process., 10, 1483-1501, 1996.

Kyllmar, K., Carlsson, C., Gustafason, A., Ulen, B., and Johnsson, H.: Nutrient discharge from small agricultural catchments in Sweden: Characterisation and trends, Agr. Ecosyst. Environ., 115, 15-26, 2006.

Lalor, S. T. J., Coulter, B. S., Quinlan, G., and Connolly, L.: A survey of fertilizer use in Ireland from 2004-2008 for grasslands and arable crops, Johnstown Castle Environment Research Centre, Wexford, Ireland, 2010.

Lu, X. X., Li, S., He, M., Zhou, Y., Bei, R., Li, L., and Ziegler, A. D.: Seasonal changes of nutrient fluxes in the Upper Changjiang basin: An example of the Longchuanjiang River, China, J. Hydrol., 405, 344-351, 2011. 
Mainstone, C. P., Dils, R. M., and Withers, P. J. A.: Controlling sediment and phosphorus transfer to receiving waters - A strategic management perspective for England and Wales, J. Hydrol., 350, 131-143, 2008.

Marchetti, R. and Verna, N.: Quantification of the phosphorus and nitrogen loads in the minor rivers of the Emilia-Romagna coast (Italy), A methodological study on the use of theoretical coefficients in calculating loads, Sci. Total Environ., Suppl., 315-336, 1992.

May, L., House, W. A., Bowes, M., and McEvoy, J.: Seasonal export of phosphorous from a lowland catchment: upper River Cherwell in Oxfordshire, England, Sci. Total Environ., 269, 117-130, 2001.

McDowell, R. W., Biggs, B. J. F., Sharpley, A. N., and Nguyen, L.: Connecting phosphorus loss from agricultural landscapes to surface water quality, J. Chem. Ecol., 20, 1-4, 2004.

McGarrigle, M. and Clenaghan, C.: Agriculture and Forestry, in: Ireland's Environment 2004, Environmental Protection Agency, Johnstown Castle Estate, Wexford, Ireland, 2004.

McGarrigle, M., Bradley, C., and O'Donnell, C.: Water Quality in Ireland 2007-2009, Environmental Protection Agency, Johnstown Castle Estate, County Wexford, Ireland, 2010.

Moatar, F. and Maybeck, M.: Compared performance of different algorithms for estimating annual nutrient loads discharged by the eutrophic River Loire, Hydrol. Process., 19, 429-444, 2005.

Neill, M.: Nitrate concentrations in river waters in the South-East of Ireland and their relationship with agricultural practice, Water Resour., 23, 1339-1355, 1989.

Quilbé, R., Rousseau, A. N., Duchemin, M., Poulin, A., Gangbazo, G., and Villeneuve, J.: Selecting a calculation method to estimate sediment and nutrient loads in streams: Application to the Beaurivage River (Québec, Canada), J. Hydrol., 326, 295-310, 2006.
Salvia-Castellví, M., Iffly, J. F., Borght, P. V., and Hoffman, L.: Dissolved and particulate nutrient export from rural catchments: A case study from Luxembourg, Sci. Total Environ., 344, 51-65, 2005.

Scanlon, T. M., Kiely, G., and Xie, Q.: A nested catchment approach for defining the hydrological controls on non-point phosphorus transport, J. Hydrol., 291, 218-231, 2004.

Schindler, D. W.: Recent advances in the understanding and management of eutrophication, Limnol. Oceanogr., 51, 351-363, 2006.

Smart, T. S., Hirst, D. J., and Elston, D. A.: Methods for estimation loads transported by rivers, Hydrol. Earth Syst. Sci., 3, 295-303, doi:10.5194/hess-3-295-1999, 1999.

Stutter, M. I., Langan, S. J., and Demars, B. O. L.: River sediments provide a link between catchment pressures and ecological status in a mixed land use Scottish river system, Water Res., 41, 28032815, 2007.

Webb, B. W. and Walling, D. E.: Nitrate behaviour in streamflow in a grassland catchment in Devon, U.K., Water Resour., 19, 10051016, 1985.

Withers, P. J. A., Edwards, A. C., and Foy, R. H.: Phosphorus cycling in UK agriculture and implications for phosphorus loss from soil, J. Soil Use Manage., 17, 139-149, 2001.

Zamyadi, A., Gallichand, J., and Duchemin, M.: Comparison of methods for estimating sediment and nitrogen loads from a small agricultural watershed, Can. Biosyst. Eng., 49, 1.27-1.36, 2007. 